\title{
Assessment of Monocyte/HDL Ratio in Patients with Acute Appendicitis
}

\section{Akut Apandisitli Hastalarda Monosit/HDL Oranının Değerlendirilmesi}

\author{
(1) Adnan Kuvvetli1, (1) Hilmi Erdem Sümbül2, @ Mevlüt Koç3 \\ 1 University of Health Sciences Turkey, Adana Health Practice and Research Center, Department of General Surgery, Adana, Turkey \\ 2University of Health Sciences Turkey, Adana Health Practice and Research Center, Department of Internal Medicine, Adana, Turkey \\ 3University of Health Sciences Turkey, Adana Health Practice and Research Center, Department of Cardiology, Adana, Turkey
}

\section{\|II\|\|\|I| ABSTRACT}

Aim: In patients with acute appendicitis (AA), the number of monocytes increase and the level of high-density lipoprotein cholesterol (HDL-C) decrease. The monocyte/HDL-C ratio (MHR) has recently been used as a diagnostic and prognostic marker for acute inflammation. As far as we research in the literatures, there is no information about the use or alteration of MHR in patients with AA. The aim of this study was to investigate the MHR change in patients with AA and its utility for this disease.

Methods: This cross-sectional study includes 206 patients with AA and 57 healthy controls that are similar in age and sex. Serum lipid panel was measured in all patients in addition to routine history, physical examination and laboratory evaluations. Patients were divided into two groups with and without AA and all data were compared.

Results: MHR was significantly higher in patients with AA (17.5 \pm 9.9 vs $8.5 \pm 1.6$ and $\mathrm{p}<0.001)$. Perforation was detected in 32 (15.5\%) patients with AA. MHR was significantly higher in patients with perforation than non-perforated patients $(16.1 \pm 8.46$ vs $23.5 \pm 9.34$ and $p<0.001)$. Laboratory data showed that white blood cell count, monocyte, lymphocyte, neutrophil, triglyceride and neutrophil/lymphocyte ratio (NLR) levels were higher in patients with AA; serum HDL cholesterol levels were lower ( $\mathrm{p}<0.05$ for each-one). In logistic regression analysis, it was determined that MHR and NLR values independently determined AA patients. The area under the curve was most for MHR and the area under the curve was 0.865 and 0.780 for MHR and NLR, respectively. In this analysis, when the cut-off value for MHR was taken as 10, it was found that it detected the patients with AA with a sensitivity of $80.4 \%$ and a specificity of $81.8 \%$.

Conclusion: In our study, it was found for the first time that MHR value was significantly increased in patients with AA. In addition to the classical diagnostic examinations in patients presenting to the emergency department with the diagnosis of AA; MHR can also be used in diagnostic approach as a simple, easily accessible, inexpensive and objective parameter.

Keywords: Acute appendicitis, monocyte/HDL ratio, emergency department

\section{|IIIIIII| ÖZ}

Amaç: Akut apandisit (AA) hastalarında monosit sayısı artar ve yüksek-dansiteli lipoproteyin kolesterol düzeyi (HDL) ise azalmaktadır. Monosit/ HDL-C oranı (MHR) son günlerde akut inflamasyon durumda tanısal ve prognostik bir belirleyici olarak kullanılmaktadır. Literatürde araştırdığımız kadarı ile AA hastalarında MHR değişimi veya kullanımı ile ilgili bilgi yoktur. Bu çalışmada AA hastalarında MHR değişimini ve bunun bu hastalık için kullanılabilirliğinin araştırılması amaçlandı.

Yöntem: Bu cross-sectional çalışmaya AA olan 206 hasta ve yaş ile cinsiyet olarak benzer AA olmayan 57 kontrol alındı. Tüm hastalara rutin anamnez, fizik muayene ve laboratuvar değerlendirmelerine ek olarak serum lipid paneli ölçüldü. Hastalar AA olan ve olmayan olarak 2 gruba ayrılarak tüm veriler karşılaştırıldı.

Bulgular: AA olan hastalarda MHR anlamlı olarak yüksekti $(17,5 \pm 9,9$ ve 8,53 $\pm 1,56$ ve p<0,001). Otuz iki (\%15,5) AA hastasında perforasyon saptandı. Perforasyon olan hastalarda perfore olmayanlara göre de MHR anlamlı olarak yüksekti $(16,1 \pm 8,46$ ve $23,5 \pm 9,34$ and p<0,001). Laboratuvar verilerinden WBC sayısı, monosit, lenfosit ve nötrofil, trigliseride ve nötrofil/lenfosit ratio (NLR) düzeylerinin AA olan hastalarda yüksek; serum HDL kolesterol düzeyi ise düşüktü ( $p<0,05$ her biri için). Lojistik regresyon analizinde, MHR ve NLR değerlerinin AA olan hastaları bağımsız olarak belirlediği saptandı. Buna analize göre MHR ve NLR değerlerindeki her 0,2 mm artışın AA olma riskini sırası ile 3.8 ve 1.4 kat artırdığı saptandı. Ayrıca

Address for Correspondence/Yazışma Adresi: Adnan Kuvvetli MD,

University of Health Sciences Turkey, Adana Health Practice and Research Center, Department of General Surgery, Adana, Turkey

E-mail: dradnankuvvetli@hotmail.com ORCID ID: orcid.org/0000-0002-0725-6629

Received/Geliş Tarihi: 10.01.2020 Accepted/Kabul Tarihi: 16.02.2020

${ }^{\circledR}$ Copyright 2020 by Turkish Society of Colon and Rectal Surgery

Turkish Journal of Colorectal Disease published by Galenos Publishing House. 
AA olan hastaları belirlenmesi için ROC eğri analizi yapıldı; eğri altında kalan alan en fazla MHR olduğu ve eğri altında kalan alanın MHR ve NLR için sırası ile 0,865 ve 0,780 olduğu bulundu. Bu analizde MHR için sınır değeri 10 olarak alındığında, AA olan hastaları \%80,4 duyarlılık ve \%81,8 özgüllük ile belirlediği tespit edildi.

Sonuç: Çalışmamızda ilk kez AA hastalarında MHR değerinin anlamlı olarak arttığı bulundu. Acil servise AA ön tanısı ile gelen hastalarda klasik tanısal incelemelere ek olarak; basit, kolay ulaşılabilen, ucuz ve objektif bir parametre olarak MHR da tanısal yaklaşımda kullanılabilir.

Anahtar Kelimeler: Akut apandisit, monosit/HDL oranı, acil servis

\section{Introduction}

Acute appendicitis (AA) is the most common cause of acute abdomen in all age groups who present to the emergency department. Acute inflammation increases with the disease in the course; oxidative stress, endothelial dysfunction, and increased local and systemic inflammatory biomarkers., ${ }^{1,2}$ The number of monocytes from the white blood cell (WBC) and its subtypes is also increased. . $^{2,3}$ AA is a disease that starts locally and increases systemically with inflammation. Patients with AA have an increase in WBC, lymphocyte, neutrophil and monocyte counts., ${ }^{2,3}$ The increase of lymphocyte percent is higher than neutrophil increase and therefore studies have shown that neutrophil/lymphocyte ratio (NLR) is higher in patients with AA. . $3,3,4,5,6,7,8,9$ It has been reported that NLR can be used for diagnostic purposes in patients with AA. ${ }^{6,7,8,9}$ High density lipoprotein (HDL) cholesterol has anti-inflammatory and anti-oxidant effects, and serum HDL cholesterol decreases in many systemic inflammations including myocardial infarction..$^{5,10}$

Systemic inflammation in AA leads to an increase in inflammation and a decrease in HDL cholesterol levels and activity. ${ }^{11,12}$ Increased monocyte and decreased HDL cholesterol levels and the ratio of these two parameters to monocyte/HDL ratio (MHR) have been shown in the literature in many inflammatory diseases. ${ }^{10,13,14,15,16,17,18,19,20,21}$ It has also been found that this parameter, such as NLR, is a diagnostic approach to many inflammatory diseases, as well as the severity of inflammation and a prognostic marker. ${ }^{10,13,14,15,16,17,18,19,20,21,22,23}$ In patients with AA, the number of monocytes increases and the level of high-density lipoprotein cholesterol (HDL-C) decrease. The monocyte/ HDL-C ratio (MHR) has recently been used as a diagnostic and prognostic marker for acute inflammation. To the best of our knowledge, there is no information about the MHR change or diagnostic use in AA patients and whether it is a prognostic marker. We have hypothesized that MHR will increase with increasing monocyte and decreasing HDL cholesterol levels in AA patients.

Therefore, the aim of this study was to investigate the MHR change in AA patients and its use for this disease.

\section{Materials and Methods}

\section{Study Populations}

This cross-sectional study included 263 patients who presented to our emergency department with abdominal pain. A total of 206 patients (mean age: $35.2 \pm 13.5$ years, male/ female: 129/77) who were operated for AA and diagnosed as $\mathrm{AA}$ in the pathological diagnosis, and 57 controls who were discharged from the emergency department with similar abdominal pain in age and sex but not diagnosed with AA (mean age: $50.2 \pm 10.1$ years, male/female: $31 / 26$ ). The patients who were screened to the control group were excluded from the study if they did not apply to emergency or general surgery clinics with abdominal pain for at least 1 month after discharge from the emergency department. In patients with a pre-diagnosis of AA, 14 patients whose pathological diagnosis was not associated with AA were excluded from the study. Those with active infection, recent acute coronary syndrome, secondary or malignant hypertension, pulmonary HT, abdominal aneurysm and dissection, congestive heart failure, cerebrovascular disease, moderate-severe heart valve disease, inflammatory diseases, hematological diseases, cancer and thyroid dysfunction, Moderate-severe hepatic and renal failure was excluded from the study due to the fact that MHR could increase. In addition, patients $<18$ years of age, pregnancy or suspicion of pregnancy, $<18$ years of age and who did not accept the study were excluded from the study. The study was approved by the regional ethics committee, all patients included in the study were informed about the study and a revised consent form was obtained.

Firstly, a detailed history was taken and physical examinations of all patients were performed. Demographic characteristics and clinical parameters of the all patients were recorded. Height and weight were measured and body mass index was calculated. AA was initially diagnosed clinically. In addition, the ALVARADO and RIPASA scoring systems were used for all patients in the emergency department. ${ }^{24,25}$ However, ultrasound (US) and computerized tomography (CT) support was also obtained from radiological evaluations in patients who could not be diagnosed clinically. However, these two examinations were not evaluated because they were not present in all cases. 


\section{Biochemical Measurements}

Venous blood samples were obtained at polyclinic admission. Samples were taken from cubital vein into blood tubes. Blood counts were measured by a Sysmex K-1000 (Block Scientific, Bohemia, New York) auto analyzer within 5 min of sampling. Serum glucose, blood urea nitrogen, creatinine, total cholesterol, low-density lipoprotein cholesterol, highdensity lipoprotein (HDL) cholesterol, triglyceride, hs$\mathrm{CRP}$ and uric acid concentrations were measured with an automated chemistry analyzer (Abbott Aeroset, Minnesota, USA) using commercial kits (Abbott).

\section{Statistical Analysis}

All analyzes were performed using SPSS 22.0 (Chicago, IL, USA) statistical software package. Kolmogorov-Smirnov test was used to determine whether the distribution of continuous variables was normal. Continuous variables in the group data were expressed as mean \pm standard deviation. Categorical variables were expressed as numbers and percentages. Student's t-test was used for the comparison of continuous variables between groups. However, MannWhitney $\mathrm{U}$ test was used for the evaluation of non-normal distribution parameters. Chi-square test was used to compare categorical variables. Logistic regression analysis was used to determine the parameters that independently identified patients with AA. In addition, ROC curve analysis was performed for MHR to identify patients with AA. Multivariate linear regression analysis was performed for the association of MHR with Alvarado and RIPASA. Statistical significance was accepted if $\mathrm{p}<0.05$.

\section{Results}

Mean, median, minimum and maximum MHR values of all patients with AA were 17.5 $\pm 9.9,15.6,4.61$ and 47.5 respectively. The mean, median, minimum and maximum MHR values of the non-AA control group were $8.53 \pm 1.56$, $8.78,4.61$ and 10.9 respectively. The study population was divided into two groups with and without AA and all parameters were compared. Thirty-two (15.5\%) of the patients with AA included in the study had perforation. Demographic, clinical and laboratory findings of the study groups were compared. When the demographic and clinical data of both groups were examined, all demographic and clinical parameters were found to be similar between the two groups (Table 1). Laboratory data showed that WBC

Table 1. Demographic, clinic and laboratory findings in patients with acute appendicitis and controls

\begin{tabular}{|c|c|c|c|}
\hline & $\begin{array}{l}\text { Acute appendicitis } \\
\mathrm{n}=206\end{array}$ & $\begin{array}{l}\text { Controls } \\
\mathrm{n}=57\end{array}$ & $\mathrm{p}$ \\
\hline Age (year) & $35.2 \pm 13.5$ & $34.3 \pm 10.2$ & 0.629 \\
\hline Gender (male) & 129 & 31 & 0.202 \\
\hline Body mass index $\left(\mathrm{kg} / \mathrm{m}^{2}\right)$ & $25.1 \pm 2.8$ & $25.0 \pm 3.1$ & 0.987 \\
\hline Hospitalization day & $3.27 \pm 1.81$ & - & - \\
\hline ALVARADO & $7.31 \pm 2.23$ & - & - \\
\hline RIPASA & $10.01 \pm 2.96$ & - & - \\
\hline White blood cell count () & $13.5 \pm 6.5$ & $8.04 \pm 1.45$ & $<0.001$ \\
\hline Red blood cell count & $4.76 \pm 0.60$ & $4.63 \pm 0.60$ & 0.220 \\
\hline Hemoglobin & $14.8 \pm 2.7$ & $13.2 \pm 2.1$ & 0.265 \\
\hline Platelet $\left(\times 10^{9} / \mathrm{L}\right)$ & $252 \pm 81$ & $247 \pm 99$ & 0.820 \\
\hline Monocyte $\left(\times 10^{9} / \mathrm{L}\right)$ & $661 \pm 228$ & $402 \pm 72$ & 0.001 \\
\hline Lymphocyte $\left(10^{\wedge} 3 / \mu \mathrm{L}\right)$ & $1.74 \pm 0.98$ & $2.11 \pm 0.62$ & 0.465 \\
\hline Neutrophil $\left(10^{\wedge} 3 / \mu \mathrm{L}\right)$ & $9.3 \pm 4.7$ & $3.6 \pm 1.1$ & 0.001 \\
\hline Mean platelet volume (fL) & $9.21 \pm 1.38$ & $8.42 \pm 0.97$ & 0.413 \\
\hline Total Cholesterol (mg/dL) & $203 \pm 41$ & $198 \pm 44$ & 0.392 \\
\hline LDL Cholesterol (mg/dL) & $135 \pm 35$ & $133 \pm 33$ & 0.638 \\
\hline HDL Cholesterol (mg/dL) & $41.4 \pm 6.23$ & $48.3 \pm 1.68$ & $<0.001$ \\
\hline Trigliserid (mg/dL) & $200 \pm 101$ & $159 \pm 77$ & 0.005 \\
\hline Neutrophil/ Lymphocyte ratio & $9.1 \pm 9.1$ & $1.8 \pm 0.67$ & $<0.001$ \\
\hline Monocyte/HDL ratio & $17.5 \pm 9.9$ & $8.53 \pm 1.56$ & $<0.001$ \\
\hline
\end{tabular}

HDL: High density lipoprotein, LDL: Low density lipoprotein 
counts, monocyte, lymphocyte and neutrophil, triglyceride, NLR and MHR levels were higher in patients with AA; serum HDL cholesterol level was low (Table 1). Other laboratory parameters were similar between the two groups (Table 1). Logistic regression analysis was performed to determine the most effective parameters determining the presence of AA among the different parameters in AA and non-AA patient groups. Among these parameters, only MHR and NLR values independently determined patients with AA (Table 2). According to this analysis, each $0.2 \mathrm{~mm}$ increase in MHR and NLR values increased the risk of AA to 3.8 and 1.4 times, respectively (Table 2). Also in the linear regression analysis, only MHR was independently associated with the Alvarado and RIPASA scores of the diagnostic scores for AA ( $p<0.001$ and $\beta=0.420$ and $p<0.001$ and $\beta=0.382$ ). In the same analysis, NLR and Alvarado and RIPASA scores were not independently related. MHR was significantly higher in patients with perforated AA than in non-perforated AA group ( $16.1 \pm 8.46$ vs. $23.5 \pm 9.34$ and $p<0.001)$.

ROC curve analysis was also performed to identify patients with AA; the parameters under the curve $>0.700$ are shown in Table 3. The area under the ROC curve was found to be the most MHR and the area under the curve was 0.865 and 0.780 for MHR and NLR, respectively. In this analysis, when the cut-off value for MHR was taken as 10, it was found that it identified patients with AA with a sensitivity of $80.4 \%$ and a specificity of $81.8 \%$. When the cut-off value for NLR was taken as 12.4, it was found that it determined the patients with AA with $71.2 \%$ sensitivity and $70.4 \%$ specificity.

\section{Discussion}

The most important finding of our study was that the MHR value in patients with AA was higher than in non-AA controls. According to our research, this is the first study to demonstrate increased MHR in patients with AA. Another important finding is that in patients with AA, MHR is more significantly associated with ALVARADO and RIPASA scores than AA. When the MHR cut-off value is taken as 10 , it determined the patients with advanced AA with acceptable sensitivity and specificity. In addition, MHR was significantly higher in AA patients than in non-perforated patients.

In inflammatory diseases, elevated local and systemic inflammation biomarkers and their amount are used both in the diagnosis and prognosis of these diseases. WBC and its subtypes increase in diseases leading to acute local and systemic infection and inflammation. They cause an increase in the activation of inflammatory cells in these cells, and then increase the activity of each other through a vicious cycle. With the diagnosis and subsequent treatment, this inflammatory cell and its markers decrease and change in time depending on the course of the disease. Many recent studies have shown that NLR is increased in cardiovascular and systemic diseases such as atrial fibrillation, diabetes mellitus, atherosclerosis, and myocardial infarction..$^{26,27,28}$ A similar situation has been shown in several studies involving patients with AA. ${ }^{6,7,8,9}$ In patients with AA, NLR is significantly more pronounced in this disease than lymphocyte count is higher than the neutrophil count, but both cell groups are significantly increased. ${ }^{2,3,4}$ The results of NLR in patients with AA were supportive of previous studies in the literature. It was once again shown that NLR was significantly increased in patients with AA and that it could be used as an auxiliary laboratory parameter in the diagnosis of AA. However, diagnostic strength for AA was lower than MHR.

Another increasing blood cell in patients with AA was monocytes. ${ }^{2,3,4}$ Monocytes are indicators of inflammatory reactions because monocytes are responsible for the secretion of proinflammatory and pro-oxidant cytokines. ${ }^{2}$

HDL cholesterol reduces the accumulation of macrophages by sweat interaction with monocytes, increases NO synthase from the endothelium, and inhibits monocyte transmission

Table 2. According to multivariate regression analysis, independent risk factors for occurrence of acute appendicitis

$\begin{array}{lllll} & \text { Odds ratio } & 95 \% \text { Confidence interval } & \text { p } & 0.006 \\ \text { Monocyte/HDL ratio (each 0.2) } & 3.802 & 1.468-9.844 & 0.014\end{array}$

HDL: High density lipoprotein

Table 3. ROC curve analysis of monocyte/HDL and neutrophil/lymphocyte ratios for acute appendicitis

$\begin{array}{lcccc}\text { Variable } & \text { Area under ROC curve } & \mathrm{p} & \text { Cut-off value } & \text { Sensitivity } \\ \text { Monocyte/HDL ratio } & 0.865(0.823-0.907) & <0.001 & 10.0 & 80.4 \% \\ \text { Neutrophil/Lymphocyte ratio } & 0.780(0.700-0.859) & <0.001 & 12.4 & 71.2 \%\end{array}$

HDL: High density lipoprotein, ROC: Receiver operating characteristic 
from the endothelium and has an anti-inflammatory and anti-oxidant effect. ${ }^{5}$ Unfortunately, although the exact cause is unknown, HDL cholesterol levels and activity are reduced in inflammatory diseases. ${ }^{5,10}$ This is the case in patients with AA and HDL cholesterol levels decrease. ${ }^{11,12}$ In our study, HDL cholesterol decreased, while triglyceride level increased. Reduction of HDL cholesterol in inflammation as well as the reduction of both inflammation and cytokines synthesis from the liver, HDL can be used indirectly to suppress inflammation. MHR is a recently introduced parameter that can be measured simply by correlating inflammation and oxidative stress in the body. ${ }^{10,13,14,15,16,17}$, $18,19,20,21,29$ It is also a prognostic parameter. ${ }^{16,20,22,23}$ Because of this condition, a lot of studies have been made on MHR in acute coronary syndrome, stroke, hypertension, renal failure, heart failure, infective endocarditis, obstructive sleep apnea, atherosclerotic processes, coronary artery disease, myocardial infarction, cardiovascular prognosis, but MHR has not been studied in AA. ${ }^{16}$

However, AA also monocyte and HDL are inversely changing and it is evident that there may be an increase in MHR. For the first time in our study, MHR is more clearly diagnosed by MHR than both WBC and related blood cells and NLR. When the MHR is taken as a cut-off value of $>10$ for the diagnosis of AA, it makes the diagnosis of AA with acceptable sensitivity and specificity. In addition, every 0.2 unit increase in MHR increases the risk of AA being 3.8 times.

Traditionally, AA is diagnosed clinically. However, in many studies, some formulas have been developed for difficult cases and scenarios. ${ }^{30}$ Some surgeons use scoring systems such as Alvarado and RIPASA. ${ }^{24,25}$ In addition, US and CT support is also support is also obtained from routine radiological evaluations. ${ }^{31}$ The fact that CT expose ionizing radiation and is expensive, and US is operator dependent, are the major disadvantage of radiological evaluations. Therefore, most surgeons are currently using anamnesis, physical examination, laboratory results and clinical scoring systems. According to the results of our study, WBC, NLR and MHR can be used in the emergency department in the diagnosis of AA.

In patients with AA, perforation is in the range of 18$34 \% .^{32}$ Early diagnosis is important in this condition, which may cause mortality, especially in the elderly. ${ }^{33}$ Both total WBC count and NLR have been significantly increased in patients with perforated AA compared to non-perforated patients. ${ }^{3,34,35}$ Similarly, in our study, MHR was also increased in patients with perforated AA.

\section{Study Limitations}

In this study, MHR was studied cross-sectionally in patients with AA. We included a relatively small number of patients, but showed that MHR was significantly increased in patients with AA. The study could have been more meaningful if it was performed prospectively and with more patients. In our study, due to the first use of MHR, there were no limit values in previous studies. Therefore, it should be supported by more randomized, multicenter studies involving different patients. US and CT imaging methods are used in the diagnosis of AA. ${ }^{8}$ However, we did not evaluate this technique and its results in our study due to the absence of these two examinations to all patients in our study. In addition, no correlation was found between CT and US findings and MHR.

\section{Conclusion}

As a result of our study, it was concluded that the ratio of HDL cholesterol levels, WBC parameters, HDL cholesterol levels are simple, inexpensive and objective MHR values in patients diagnosed with AA in Emergency department as an adjunct to other diagnostic methods in the diagnosis of AA and the severity of the disease. However, our study was the first to evaluate MHR in patients with AA. Therefore, the data in our study should be supported by new and more multicenter studies.

\section{Ethics}

Ethics Committee Approval: Adana City Training and Research Hospital, Clinical Research Ethics Committee (24.04.2019).

Informed Consent: All patients included in the study were informed about the study and a revised consent form was obtained.

Peer-review: Internally and externally peer reviewed.

\section{Authorship Contributions}

Surgical and Medical Practices: A.K., Concept: A.K., H.E.S., M.K., Design: A.K., H.E.S., M.K., Data Collection or Processing: A.K., H.E.S., M.K., Analysis or Interpretation: M.K., A.K., Literature Search: A.K., M.K., Writing: A.K.

Conflict of Interest: No conflict of interest was declared by the authors.

Financial Disclosure: The authors declared that this study received no financial support.

\section{References}

1. Heitzer T, Schlinzig T, Krohn K, Meinertz T, Münzel T. Endothelial dysfunction, oxidative stress, and risk of cardiovascular events in patients with coronary artery disease. Circulation 2001;104:2673-2678.

2. Ancuta P, Jianbin W, Gabuzda D. CD16+ monocytes produce IL-6, CCL2 and matrix metalloproteinase-9 upon interaction with CX3CL1-expressing endothelial cells. J Leukoc Biol 2006;80:1156-1164.

3. Wilson EB, Cole JC, Nipper ML, Cooney DR, Smith RW. Computed tomography and ultrasonography in the diagnosis of appendicitis: when are they indicated? Arch Surg 2001;136:670-675. 
4. Berulava OI, Dzhalagoniia AA, Kozlov VA, Knyrkov GV, Kurkin AV. Changes in the peripheral blood picture in acute appendicitis in relation to accelerated development. Vestn Khir Im I I Grek 1981;126:35-37.

5. Murphy AJ, WoollardKJ. High-densitylipoprotein: a potent inhibitor of infammation. Clin Exp Pharmacol Physiol 2010;37:710-718.

6. Akgül N, Gundes E. Neutrophil/Lymphocyte Ratio in Acute Appendicitis: A State Hospital Experience. Turk J Colorectal Dis 2016;26:121-124.

7. Kucuk A, Erol MF, Senel S, Eroler E, Yumun HA, Uslu AU, Erol AM, Tihan D, Duman U, Kucukkartallar T, Solak Y. The role of neutrophil lymphocyte ratio to leverage the differential diagnosis of familial Mediterranean fever attack and acute appendicitis. Korean J Intern Med 2016;31:386-391.

8. Khan A, Riaz M, Kelly ME, Khan W, Waldron R, Barry K, et al.Prospective validation of neutrophil-to-lymphocyte ratio as a diagnostic and management adjunct in acute appendicitis.Ir J Med Sci. 2018;187:379384.

9. Jung SK, Rhee DY, Lee WJ, Woo SH, Seol SH, Kim DH, et al. Neutrophil-tolymphocyte count ratio is associated with perforated appendicitis in elderly patients of emergency department. Aging Clin Exp Res 2017;29:529-536.

10. Şatırtav G, Mirza E, Oltulu R, Mirza GD, Kerimoğlu H. Assessment of Monocyte/HDL Ratio in Branch Retinal Vein Occlusion. Ocul Immunol Inflamm 2019;9:1-5.

11. Garbagnati E. Changes in lipid profile observed in children over the course of infectious disease. Acta Paediatr 1993;82:948-952.

12. Osochuk SS, Konevalova NIu.Changes in the fat-acid spectrum of high-density lipoproteins as observed in men and women with acute appendicitis. Klin Lab Diagn 2005;1:8-11.

13. Mirza E, Oltulu R, Katipoğlu Z, Mirza GD, Özkağnıcı A. Monocyte/HDL ratio and lymphocyte/monocyte ratio in patients with pseudoexfoliation syndrome. Ocul Immunol Infamm 2018;1-5.

14. Kormaz A, Demir M, Unal S, Yildiz A, Ozyazgan B, Demirtas B, et al. Monocyte-to-high density lipoprotein ratio (MHR) can predict the signifcance of angiographically intermediate coronary lesions. Int J Cardiovas Acad 2017;3:16-20

15. Bolayir A, Gokce SF, Çiğdem B, Bolayir HA, Kayım Yildiz O, Bolayir E, et al. Monocyte/highdensity lipoprotein ratio predicts the mortality in ischemic stroke patients. Neurol Neurochir Pol 2018;52:150-155.

16. Ganjali S, Gotto AM Jr, Ruscica M, Atkin SL, Butler AE, Banach M, et al. Monocyte-to-HDL-cholesterol ratio as a prognostic marker in cardiovascular diseases. J Cell Physiol 2018;233:9237-9246.

17. Açıkgöz SK, Açıkgöz, E, Şensoy B, Topal S, Aydoğdu S. Monocyte to high-density lipoprotein cholesterol ratio is predictive of in-hospital and five-year mortality in ST-segment elevation myocardial infarction. Cardiol J 2016;23:505-512.

18. Bolayir A, Gokce SF, Cigdem B, Bolayir HA, Yildiz OK, Bolayir E, et al. Monocyte/high-density lipoprotein ratio predicts the mortality in ischemic stroke patients. Neurologia i Neurochirurgia Polska 2017;52:150-155.

19. Kundi H, Gok M, Kiziltunc E, Cetin M, Cicekcioglu H, Cetin ZG, et al. Relation between monocyte to high-density lipoprotein cholesterol ratio with presence and severity of isolated coronary artery ectasia. American Journal of Cardiology 2015;116:1685-1689.

20. You S, Zhong C, Zheng D, Xu J, Zhang X, Liu H, et al. Monocyte to HDL cholesterol ratio is associated with discharge and 3month outcome in patients with acute intracerebral hemorrhage. Journal of the Neurological Sciences 2017;372:157-161.

21. Yucetas U, Kadihasanoglu M, Karabay E, Erkan E, Ozbek E. PS-08-008 relation between monocyte to high-density lipoprotein cholesterol ratio with presence and severity of erectile dysfunction. The Journal of Sexual Medicine 2017;14:e133-e134.

22. Karataş MB, Çanga Y, Özcan KS, Ipek G, Güngör B, Onuk T, et al. Monocyte to high-density lipoprotein ratio as a new prognostic marker in patients with STEMI undergoing primary percutaneous coronary intervention. American Journal of Emergency Medicine 2016;34:240-244.

23. Cetin MS, Ozcan Cetin EH, Kalender E, Aydin S, Topaloglu S, Kisacik HL, et al. Ovascular adverse events in acute coronary syndrome. Heart Lung and Circulation 2016;25:1077-1086.

24. Gibson PH, Cuthbertson BH, Croal BL, Rae D, El-Shafei H, Gibson G, et al. Usefulness of neutrophil/lymphocyte ratio as predictor of newonset atrial fbrillation after coronary artery bypass grafting. Am J Cardiol 2010;105:186-191.

25. Ulu SM, Dogan M, Ahsen A, Altug A, Demir K, Acartük G, et al. Neutrophiltolymphocyte ratio as a quick and reliable predictive marker to diagnose the severity of diabetic retinopathy. Diabetes Technol Ther 2013;15:942 947.

26. Kuyumcu ME, Yesil Y, Oztürk ZA, Kizilarslanoğlu C, Etgül S, Halil M, et al. The evaluation of neutrophil-lymphocyte ratio in Alzheimer's disease. Dement Geriatr Cogn Disord 2012;34:69-74

27. Yilmaz M, Kayancicek H. A new infammatory marker: elevated monocyte to HDL cholesterol ratio associated with smoking. J Clin Med 2018;7:76

28. Waxman BP (2015) Treating uncomplicated appendicitis without surgery: will computer tomography scans and antibiotics triumph over clinical acumen and surgical dogma? ANZ J Surg 2015;85:80.

29. Chong CF, Adi MI, Thien A, Suyoi A, Mackie AJ, Tin AS, et al. Development of the RIPASAscore:a new appendicitis scoring system for the diagnosis of acutea ppendicitis. Singap Med J 2010;51:22-225.

30. Jang SO, Kim BS, Moon DJ. Applicationof Alvarado score in patients with suspected appendicitis. Korean J Gastroenterol 2008;52:27-31.

31. Roy H, Burbridge B. To CT or not to CT? The influence of computed tomography on the diagnosis of appendicitis in obese pediatric patients. Can J Surg 2015;58:181-187.

32. Sirikurnpiboon S, Amornpornchareon S. Factors associated with perforated appendicitis in elderly patients in a tertiary care hospital. Surg Res Pract 2015;2015:84768

33. Omari AH, Khammash MR, Qasaimeh GR, Shammari AK, Yaseen MKB Hammori SK. Acute appendicitis in the elderly: risk factors for perforation. World J Emerg Surg 2014;9:6.

34. Markar SR, Karthikesalingam A, Falzon A, Kan Y. The diagnostic value of neutrophil: lymphocyte ratio in adults with suspected acute appendicitis. Acta Chir Belg 2010;110:543-547.

35. Goodman DA, Goodman CB, Monk JS. Use of the neutrophil:lymphocyte ratio in the diagnosis of appendicitis. Am Surg 1995;61:257-259. 